\title{
Biogas production from anaerobic co-digestion using kitchen waste and poultry manure as substrate-part 1: substrate ratio and effect of temperature
}

\author{
Md Anisur Rahman ${ }^{1} \cdot$ Razu Shahazi ${ }^{1} \cdot$ Syada Noureen Basher Nova ${ }^{1} \cdot$ M. Rakib Uddin ${ }^{1,2} \cdot$ Md Shahadat Hossain $^{1}$. \\ Abu Yousuf ${ }^{1}$ (1)
}

Received: 16 March 2021 / Revised: 19 May 2021 / Accepted: 25 May 2021

(c) The Author(s), under exclusive licence to Springer-Verlag GmbH Germany, part of Springer Nature 2021

\begin{abstract}
The rapidly declining fossil fuels are no longer able to meet the ever-increasing energy demand. Moreover, they are considered responsible for greenhouse gas (GHG) emission, contributing to the global warming. On the other hand, organic wastes, such as kitchen waste (KW) and poultry manure (PM), represent considerable pollution threat to the environment, if not properly managed. Therefore, anaerobic co-digestion of KW and PM could be a sustainable way of producing clean and renewable energy in the form of biogas while minimizing environmental impact. In this study, the anaerobic co-digestion of KW with PM was studied to assess the rate of cumulative biogas (CBG) production and methane percentage in four digester setups (D1, D2, D3, and D4) operated in batch mode. Each digester setup consisted of five parallelly connected laboratory-scale digesters having a capacity of $1 \mathrm{~L}$ each. The digester setups were fed with KW and PM at ratios of 1:0 (D1), 1:1 (D2), 2:1 (D3), and 3:1 (D4) at a constant loading rate of $300 \mathrm{mg} / \mathrm{L}$ with $50 \mathrm{gm}$ cow manure (CM) as inoculum and were studied at both room temperature $\left(28^{\circ} \mathrm{C}\right)$ and mesophilic temperature $\left(37^{\circ} \mathrm{C}\right)$ over 24 days. The co-digestion of $\mathrm{KW}$ with PM demonstrated a synergistic effect which was evidenced by a $16 \%$ and $74 \%$ increase in CBG production and methane content, respectively, in $\mathrm{D} 2$ over D1. The D3 with $66.7 \% \mathrm{KW}$ and $33.3 \% \mathrm{PM}$ produced the highest $\mathrm{CBG}$ and methane percentage $(396 \pm 8 \mathrm{~mL}$ and 36\%) at room temperature. At mesophilic condition, all the digesters showed better performance, and the highest CBG $(920 \pm 11 \mathrm{~mL})$ and methane content (48\%) were observed in D3. The study suggests that co-digestion of KW and PM at mesophilic condition might be a promising way to increase the production of biogas with better methane composition by ensuring nutrient balance, buffering capacity, and stability of the digester.
\end{abstract}

Keywords Co-digestion $\cdot$ Kitchen waste $\cdot$ Poultry manure $\cdot$ Biogas $\cdot$ Degradation rate $\cdot \mathrm{C} / \mathrm{N} \cdot$ Mesophilic temperature

\section{Introduction}

KW is an unavoidable and massively produced waste from everyday cooking activities of our daily life. The quantity of $\mathrm{KW}$ is increasing day by day due to the increase of populations and changing of food habit [1]. In developing countries, KW is normally disposed off with other solid waste to

Abu Yousuf

ayousufcep@yahoo.com; ayousuf-cep@sust.edu

1 Department of Chemical Engineering and Polymer Science, Shahjalal University of Science and Technology, Sylhet 3114, Bangladesh

2 Department of Engineering, Universita Degli Studi Di Napoli "Parthenope", Napoli- 80143, Italy the dustbin. Local government authorities, e.g., city corporations or municipal authorities, collect them from the bin and dump in low land without maintaining proper landfilling systems [2,3]. These scenarios are worst in the rural areas of those countries [4]. From the last decade, poultry industry has become a vital source of protein and a profitable business sector. As a result, poultry farms are increasing rapidly around the world. For instance, in the USA, the number of restaurant job increased by $84 \%$ from 2010 to 2018 where the restaurants are mostly grown based on chicken meat [5]. Apart from meeting the increasing demand of chicken meat, the chicken farms are also generating PM proportionally, of which only a tiny fraction is applied in the fishpond and the remaining are dumped in the waste bin with other solid waste. If the manure is not properly managed, they can pose serious threats to the environment including malodour, 
prevalence of pest and pathogen, water pollution, and GHG emission [6-8].

Daily per capita waste generation in Bangladesh was estimated as $0.41 \mathrm{~kg}$ in 2005 and increased to $0.56 \mathrm{~kg}$ in 2014 [9, 10]. The most recent projection made by World Bank shows that the waste generation will reach $0.75 \mathrm{~kg}$ per capita by 2025 [11]. In Bangladesh, the generated KW and PM are thrown with other waste such as plastics, paper, glass, metals, ceramics, lather, rubber, rags, grass, wood, textile, and jute in the municipal bin and termed as municipal solid waste (MSW) [12, 13]. $\mathrm{KW}$ holds the major share in MSW, and the quantity is around $70 \%$, whereas PM has the share only less than $3 \%[14,15]$. Since the KW and PM are rich in carbon and nitrogen content $[14,16]$, their continuous degradation by the action of indigenous microorganism facilitates the formation of $\mathrm{CO}_{2}, \mathrm{CH}_{4}, \mathrm{~N}_{2} \mathrm{O}$, and other gases in tiny amount [14] that continue to be released to the environment from the waste dumping sites. According to the Intergovernmental Panel on Climate Change (IPCC)'s fifth assessment report [17], $\mathrm{CH}_{4}$ and $\mathrm{N}_{2} \mathrm{O}$ are 28 and 265 times more potential as GHG compared to $\mathrm{CO}_{2}$. In addition, heavy metals present in MSW get leached out to the groundwater and cause serious water pollution, threatening aquatic and human life. With the groundwater being a major source of drinking water in Bangladesh, its pollution make people vulnerable to several debilitating waterborne diseases $[18,19]$.

To reduce the GHG emission and groundwater pollution, researchers are striving to search an alternative sustainable treatment route for MSW rather than landfilling. MSW has an energy content of $8.71 \mathrm{MJ} / \mathrm{kg}$ [14] which can be extracted by thermal treatment, e.g., incineration and gasification or biological treatment like anaerobic digestion (AD). During the incineration of MSW in a boiler, energy is recovered as heat in the form of steam or super-heated water which is used for heating, cooling, or electricity generation purposes [20]. However, incineration of MSW is associated with the emission of gaseous pollutants, such as $\mathrm{SO}_{2}, \mathrm{SO}_{3}, \mathrm{NO}$, $\mathrm{NO}_{2}, \mathrm{NO}_{3}, \mathrm{HCl}$, and $\mathrm{Cl}_{2}$ [21-24]. Moreover, due to the presence of plastics and lather in MSW, dioxins and furans are also present in the fly ash produced from incineration [25]. Therefore, to ensure the environmental safety, the exhaust gas from incineration plant needs to be treated appropriately which is costly, ultimately increasing the cost of overall energy extraction process from MSW through incineration. On the other hand, MSW typically contains moisture content of $50.56 \%$ [19]. Hence, to extract energy as syngas through gasification, the moisture content of MSW needs to be reduced to less than $10 \%$ to ensure higher process efficiency by preventing slagging formation [26-30]. However, it requires implementation of thermal drying which is energy intensive. Though the exhaust emitted from gasification of
MSW contains GHG within the permissible limit and the ash contains only the extractable heavy metals [26-30], the drying unit adds additional cost to the process of energy extraction, making it economically unfeasible.

$\mathrm{AD}$ is a biochemical process where microorganisms break down the biodegradable material of MSW in the absence of oxygen that releases the chemical energy contained within the MSW as biogas having methane (55-65\%) and $\mathrm{CO}_{2}$ $(25-45 \%)$ as major component $[31,32]$. Thus, $\mathrm{AD}$ has the potential to reduce the amount of KW by producing bioenergy in the form of methane. However, $\mathrm{AD}$ of $\mathrm{KW}$ alone comes with some limitations. Because of its having easily biodegradable organics and high $\mathrm{C} / \mathrm{N}$ ratio [33], decomposition of KW causes rapid accumulation of volatile fatty acids (VFAs). The subsequent acidification of the digester leads to lower buffering capacity and thereby lower biogas production because of the inhibition of methanogenic activity at low $\mathrm{pH}[34,35]$. To overcome this difficulty, buffer materials need to be added to ensure digester stability and better efficiency in methane production [36]. An organic buffer material could be animal manure for which the buffering capacity originates from the release of ammonia during the degradation of organic nitrogen present in the form of protein and urea [37]. Again, the produced ammonia in excess can act as an inhibiting agent against biogas-producing bacteria [38]. Hence, co-digestion of organic wastes with animal manure in proper ratio is practiced to take the advantage of easy access to organics and improved buffering capacity from organic waste and animal manure, respectively [39]. The benefits of co-digestion also includes improved biogas as well as methane yield, economic advantage derived from sharing the same equipment by different substrates, and easier management of mixed wastes, etc. [40]. Co-digestion of some animal manures, such as cattle manure [36] and pig manure [41] with KW, have been studied, and a synergistic effect in terms of improved biogas production and digester stability has been reported. However, there is little or no information regarding the co-digestion of $\mathrm{KW}$ and $\mathrm{PM}$, even though the composition of $\mathrm{PM}$ showed lower $\mathrm{C} / \mathrm{N}$ than dairy manure [42]. Hence, it is expected that the addition of PM to KW would increase the stability of the digester which would be reflected in better $\mathrm{CBG}$ production with enriched methane content.

Therefore, the aim of this study was to compare the performance of $\mathrm{AD}$ of $\mathrm{KW}$ alone with the co-digestion of $\mathrm{KW}$ and PM, and also to assess the effect of biomass ratio in co-digestion. Moreover, the same studies done at room temperature $\left(28{ }^{\circ} \mathrm{C}\right)$ were compared with that of at mesophilic temperature $\left(37^{\circ} \mathrm{C}\right)$. The efficiency of the digestion process was investigated on the basis of biomass degradation rate, biogas production, and methane percentage. 


\section{Materials and method}

\subsection{Substrate and inoculum collection}

KW was collected from different student dormitories of Shahjalal University of Science and Technology, Sylhet, 3114, Bangladesh. Bangladesh poultry farm situated at Madina Market, Sylhet, provided us with PM. Cow manure (CM) was used as a source of inoculum and was taken from a village nearby the university.

\subsection{Substrate processing and characterization}

KW was immediately subjected to a manual sorting process to get rid of non-degradable materials such as plastic bags and metallic canes. Afterward, the KW was cut into small size to get it in reduced size for ensuring efficient biogas production [43]. Then these wastes were mashed into pest by using a kitchen blender. The homogenized KW was stored in a fridge at $-20{ }^{\circ} \mathrm{C}$ before starting anaerobic digestion. The collected PM was filled with various waste such as chicken feather, jute rope, and part of brick. They were also separated from the PM manually. However, the collected cow dung was fresh and free of foreign materials and was used directly as solid innoculum without any processing. The composition of substrtaes, such as total solids (TS), volatile solids (VS), total nitrogen (TN), total carbon (TC), and $\mathrm{pH}$, was analyzed following standard methods from the American Public Health Association (APHA) [44]. The main characteristics of the substrates (KW and PM) are detailed in Table 1.

\subsection{Fabrication of digester}

A plastic bottle having a capacity of $1 \mathrm{~L}$ was used to construct the digester. A sample collector pipe was inserted through the upper face of the digester reaching up to the bottom to collect slurry for routine test. A gas collector pipe placed at the top of the digester was used to collect the gas for further analysis. The gas flow was controlled by a manually operated valve inserted in the gas collector pipe. All the

Table 1 The main characteristics of the substrates

\begin{tabular}{lcc}
\hline Characteristic parameter & KW & PM \\
\hline TS (wet basis, \%) & 65.03 & 54.90 \\
VS (wet basis, \%) & 57.11 & 48.75 \\
TC (dry basis, \%) & 63.71 & 46.55 \\
TN (dry basis, \%) & 1.81 & 4.90 \\
C/N & 35.20 & 9.5 \\
pH & 4.80 & 8.3 \\
\hline
\end{tabular}

openings of the bottle were made air-tight using M-seal to maintain anaerobic condition. The pictorial view of digester is shown in Fig. 1.

\subsection{Experimental setup}

A number of such five digesters were connected parallelly to build each of the four digester setups (D1, D2, D3, and D4), totalling to a digester volume of $5 \mathrm{~L}$ and working volume of $4 \mathrm{~L}$ during each experiment. The total volume of gas was measured by water displacement method [45]. A schematic diagram of experimental setup is illustrated in Fig. 2.

In total, two sets of experiment were conducted. In the first set of experiment, four digester setups D1, D2, D3, and D4 were filled with KW and PM (wet weight basis) at ratios of 1:0,1:1, 2:1, and 3:1, respectively. All the digesters were charged with the same amount of inoculum CM of $50 \mathrm{gm}$ at the top of the substrate and were operated at room temperature $\left(28^{\circ} \mathrm{C}\right)$ by simply putting in the laboratory at ambient condition. The same experiment was replicated for mesophilic temperature of $37^{\circ} \mathrm{C}$ by keeping the digesters in a digital thermostatic water bath that constituted the second set of experiment. The temperature was monitored on a regular basis by inserting a thermometer through the thermometer injector. Any variation in temperature was mitigated by adjusting the knob of the water bath to the desired temperature. However, in both set of experiments, the organic loading was maintained at $300 \mathrm{gm}$ per $\mathrm{L}$ volume of the digester and a retention time of 24 days was allowed for all the digesters. At every 2 days interval, $5.0 \mathrm{~mL}$ slurry was collected from each digester through the sample collector pipe with a syringe. Then the slurry was centrifuged in a tabletop centrifuge (DSC-200A-2, Digisystem Laboratory Instruments Inc., Taiwan) and the $\mathrm{pH}$ of the supernatant

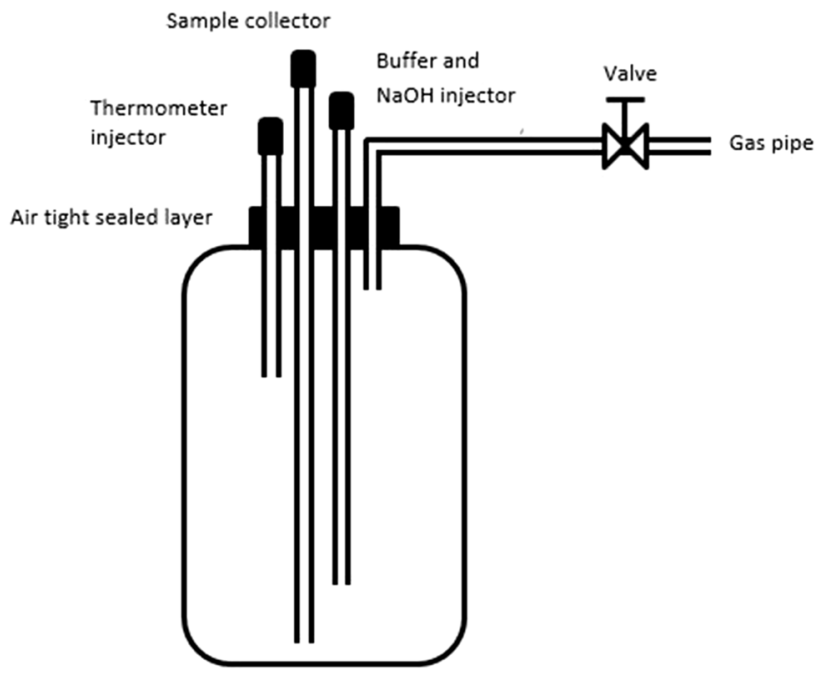

Fig. 1 Pictorial illustration of the digester 
Fig. 2 Digester setups at a room temperature $\left(28^{\circ} \mathrm{C}\right)$ and $\mathbf{b}$ mesophilic temperature $\left(35^{\circ} \mathrm{C}\right)$

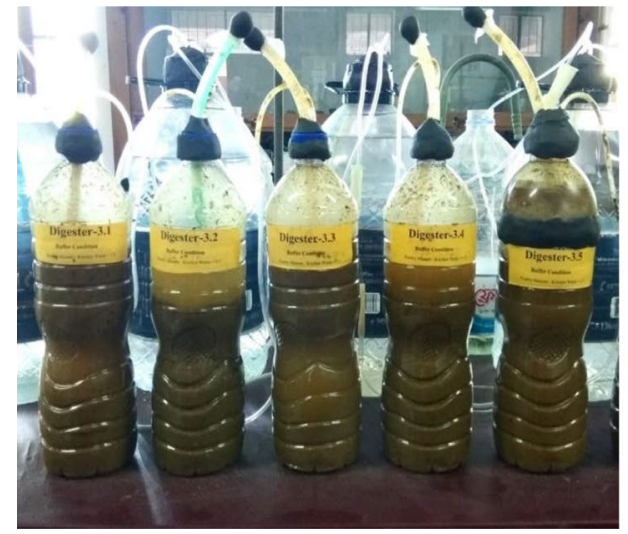

(a)

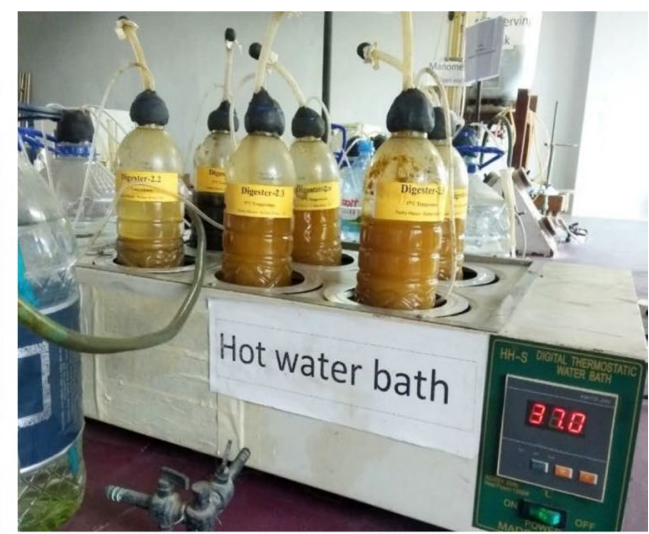

(b)
Table 2 The amount of substrates in different digester setups

\begin{tabular}{lllrlr}
\hline $\begin{array}{l}\text { Digester } \\
\text { setup }\end{array}$ & $\begin{array}{l}\text { Ratio } \\
\text { (KW:PM) }\end{array}$ & $\begin{array}{l}\text { Amount of }(\mathrm{gm}) \\
\text { KW }\end{array}$ & $\begin{array}{l}\text { Amount } \\
\text { of PM } \\
\text { (gm) }\end{array}$ & $\begin{array}{l}\text { Amount } \\
\text { of CM } \\
\text { (gm) }\end{array}$ & C/N \\
\hline D1 & $1: 0$ & 250.00 & 0.00 & 50.00 & 35.20 \\
D2 & $1: 1$ & 125.00 & 125.00 & 50.00 & 22.35 \\
D3 & $2: 1$ & 166.67 & 83.33 & 50.00 & 18.07 \\
D4 & $3: 1$ & 187.50 & 62.50 & 50.00 & 15.93 \\
\hline
\end{tabular}

solution was measured via electrochemical method using a digital $\mathrm{pH}$ meter. The produced gas was also measured at 2 days' interval. The ratio of substrates, amount of substrates and inoculum, and $\mathrm{C} / \mathrm{N}$ in different digester setups are depicted in Table 2. All the measurements were carried out in triplicate and the average values were taken for further explanation.

\subsection{Degradation rate measurement}

To calculate the degradation rate, total produced gas from a digester was measured and divided by the amount of substrate loaded to the corresponding digester as depicted in Eq. 1 [46].

Degradation rate $=\frac{\text { total amount of gas produced from a digester }}{\text { total amount of substrate loaded }}$

\subsection{Methane content measurement}

Biogas samples were analyzed for methane content using a gas chromatograph (Shimadzu GC-2014, Japan) system equipped with a stainless steel column packed with Unibeads C (80/100 mesh) and a thermal conductivity detector (TCD). The temperature of the injection port, column, and detector was maintained at 120,60 , and $150{ }^{\circ} \mathrm{C}$, respectively. Helium
Table $3 \mathrm{CBG}$ production at room temperature $\left(28^{\circ} \mathrm{C}\right)$ and mesophilic temperature $\left(37^{\circ} \mathrm{C}\right)$

\begin{tabular}{llcc}
\hline Digester setup & $\begin{array}{l}\text { Ratio } \\
(\mathrm{KW}: \mathrm{PM})\end{array}$ & $\begin{array}{l}\mathrm{CBG} \text { at } 28^{\circ} \mathrm{C} \\
(\mathrm{mL})\end{array}$ & $\mathrm{CBG}$ at $37^{\circ} \mathrm{C}(\mathrm{mL})$ \\
\hline D1 & $1: 0$ & $312 \pm 9$ & $532 \pm 17$ \\
D2 & $1: 1$ & $362 \pm 13$ & $614 \pm 19$ \\
D3 & $2: 1$ & $396 \pm 8$ & $920 \pm 11$ \\
D4 & $3: 1$ & $360 \pm 15$ & $452 \pm 9$ \\
\hline
\end{tabular}

was used as carrier gas with a flow rate of $50 \mathrm{~mL} / \mathrm{min}$. The analyses were carried out in triplicate and the results were reported as average on dry basis.

\section{Result and discussion}

\subsection{Synergistic effect}

Co-digestion of KW with PM demonstrated a synergistic effect in terms of CBG production due to the rapid decomposition of the KW and buffering capacity of the PM. D1 (loaded with only KW) yielded $312 \pm 9 \mathrm{~mL}$ of $\mathrm{CBG}$ while D2 (loaded with equal amount of KW and PM) produced $362 \pm 13 \mathrm{~mL}$ over the entire experimental period of 24 days at room temperature of $28{ }^{\circ} \mathrm{C}$ (Table 3 and Fig. 3 ). Hence, D2 produced $16 \%$ more biogas than the D1 at the same temperature of $28{ }^{\circ} \mathrm{C}$ and with the same amount of inoculum $50 \mathrm{~g} \mathrm{CM}$. This increase in gas production might be attributed to the synergistic effect of co-digesting $\mathrm{KW}$ and PM in a single digester. This synergistic effect comes from the combination of the desirable characteristics of the two substrates: the easy biodegradability of $\mathrm{KW}$ required for increased availability of substrates to be converted into biogas and the increase in alkalinity by PM required to keep the $\mathrm{pH}$ close to the neutral value that is prerequisite for survival of methanogenic bacteria $[39,47]$. Figure 4 illustrates 
Fig. 3 Daily biogas production at room temperature $\left(28^{\circ} \mathrm{C}\right)$
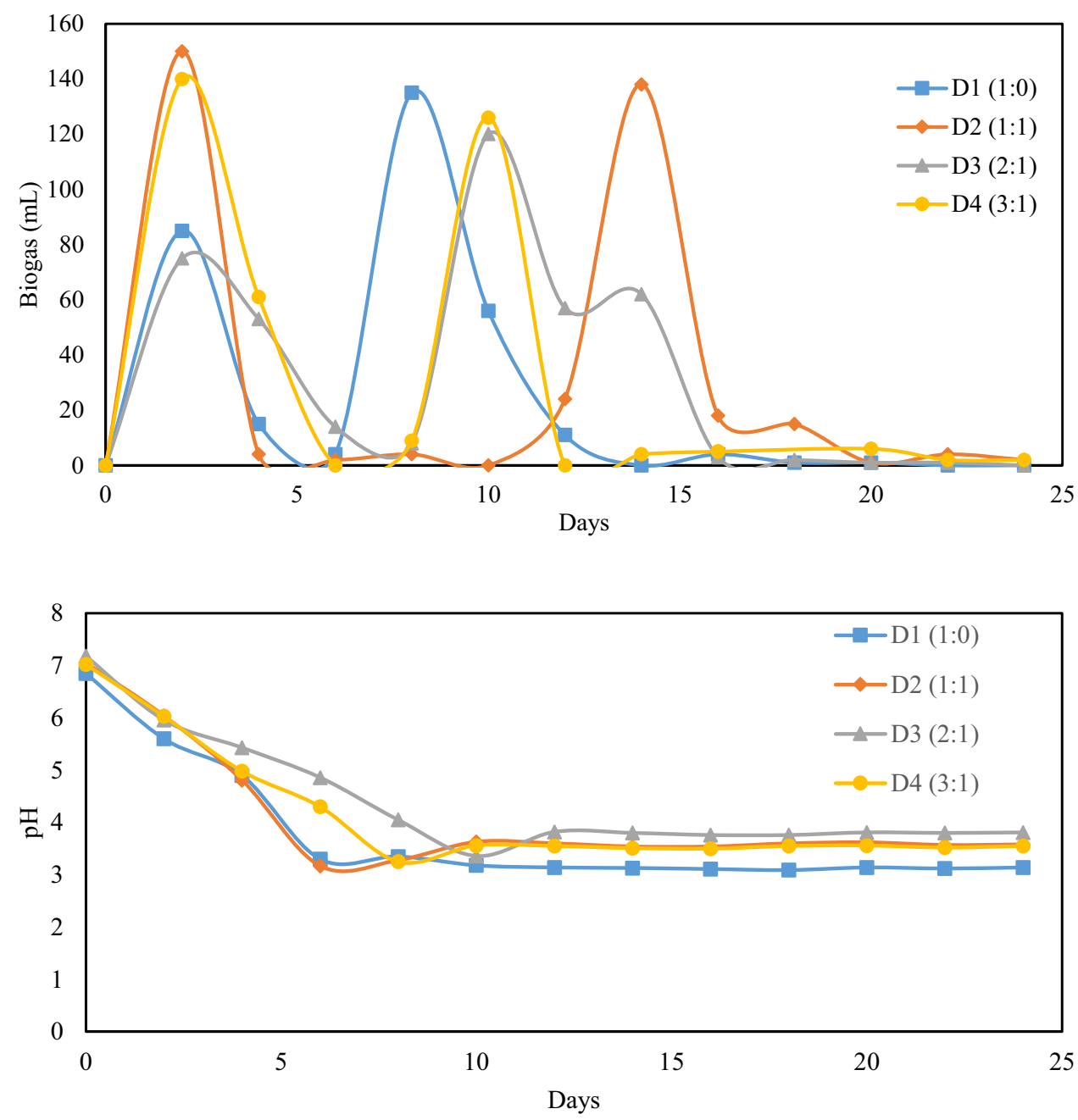

Fig. 4 Daily $\mathrm{pH}$ change during biogas production at room temperature $\left(28{ }^{\circ} \mathrm{C}\right)$ that the drop in $\mathrm{pH}$ was higher in D1 due to the rapid degradation of $\mathrm{KW}$ that might have released more VFAs [48]. Whereas in D2, the acidity was neutralized to some extent by the ammonia released from PM decomposition that kept the $\mathrm{pH}$ at higher value than that of the $\mathrm{D} 1$. The KW contains high VS content [41] that undergo rapid hydrolysis during digestion to cause serious acidification of the digester that inhibits the activity of methanogens, resulting lower gas production [34]. In contrast, the decomposition of proteins and urea in PM generates alkaline compounds like ammonia and ammonium ions that add a buffering capacity to the digester. The added buffering capacity by PM stabilize the system and lower the negative impact of VFAs on methanogens and thus contribute to higher biogas production [37, 49]. Moreover, the addition of $\mathrm{PM}$ to $\mathrm{KW}$ adjusted the mixture's $\mathrm{C} / \mathrm{N}$ ratio to 22.35, which is a favorable condition for methanogenic bacteria. Bres et al. [50] reported that the addition of poultry litter to vegetable processing waste increased the $\mathrm{C} / \mathrm{N}$ ratios in the optimal range of anaerobic digestion which varies from 13 to 28 [51]. Besides, PM is rich in biodegradable organic matter compared to other livestock excrement and thus can contribute to higher gas production [52]. However, several authors also investigated the effect of PM on different lignocellulosic waste biomasses and observed a significant increase in biogas production. Borowski et al. [53] observed a 1.5 times higher production of biogas from municipal sewage sludge when co-digested with $30 \%$ PM. In another study, sole digestion of wheat straw experienced a biogas potential of $317.5 \pm 31.3 \mathrm{~mL} / \mathrm{g} \mathrm{VS}$, whereas co-digestion of the same with the PM gave $389.7 \pm 24.7 \mathrm{~mL} / \mathrm{g}$ VS biogas [42]

\subsection{Biogas production at different biomass ratios}

Biogas production was studied at different biomass ratios to achieve the optimum substrate ratio in co-digestion of $\mathrm{KW}$ and PM. Change in substrate ratios has impact on the daily biogas production and the $\mathrm{pH}$ of the digesters. The daily biogas production at room temperature and the corresponding $\mathrm{pH}$ change in four digester setups (D1 to D4) are shown in Figs. 3 and 4.

All the digesters displayed a similar trend in biogas production as well as in change of $\mathrm{pH}$. In general, the gas 
production (Fig. 3) increased during the first couple of days that might be due to the degradation of soluble carbohydrates available in KW. Afterward, it decreased sharply due to drop in $\mathrm{pH}$ owing to possible accumulation of VFAs that led to instability in the growth of microorganism. This phenomenon can also be attributed to the difficulty in biological degradation of complex compounds after the conversion of easily degradable organic fractions $[54,55]$. Then gas production increased again due to the gradual acclimation of the microorganisms to the treatment media followed by a permanent cease in gas production because the microorganisms could not sustain the environment below the neutral $\mathrm{pH}$ [34]. Several studies reported that the optimal $\mathrm{pH}$ for methanogenesis is about 7.0, whereas for hydrolysis and acidogenesis, it is between 5.5 and 6.5 [56, 57]. The pH (Fig. 4) of all digesters dropped initially at a steady pace up to 6 to 10 days and then maintained a plateau value until the gas production is stopped. The $\mathrm{pH}$ drop in $\mathrm{D} 1$ was at a higher rate than the others, which may be due to the rapid VFA production from decomposition of $\mathrm{KW}$ alone, i.e., high nutrient to microorganism ratio [36], and fell to the plateau value, around 3.1, after 6 days. In other digesters, the $\mathrm{pH}$ drops were slower due to the alkaline effect stemming from the PM decomposition, with $\mathrm{D} 3$ being the lowest $\mathrm{pH}$ drop experiencing digester. It took 10 days for $\mathrm{D} 3$ to fall to $\mathrm{pH} 3.8$ and remained at that value over the rest of the period. The $\mathrm{pH}$ in $\mathrm{D} 2$ and $\mathrm{D} 4$ were somewhere in between that of the D1 and D3.

During the co-digestion of $\mathrm{KW}$ and $\mathrm{PM}$ at room temperature $\left(28^{\circ} \mathrm{C}\right)$, the $\mathrm{CBG}$ (Table 3 ) increased from $362 \pm$ $13 \mathrm{~mL}$ in $\mathrm{D} 2$ to $396 \pm 8 \mathrm{~mL}$ in $\mathrm{D} 3$ and then dropped to 360 $\pm 15 \mathrm{~mL}$ in $\mathrm{D} 4$. This indicates that the CBG increased with increasing amount of KW up to twofold of PM in D3 and then decreased for a threefold of PM in D4. Compared to the $\mathrm{pH}$ (about 3.8) of the digester setup D3 at plateau condition (as shown in Fig. 4), the $\mathrm{pH}$ of D2 and D4 are (around 3.5) far away from the neutral value, which might led to more instability in the later digester setups and consequently lower gas production. In D4, alkaline effect of 25\% PM was not sufficient to decrease the negative impact of VFAs from $75 \% \mathrm{KW}$. In contrast, the lower gas production in D2 might be attributed to the inhibitory effect of high concentration of ammonia from increased amount of PM which was 50\% [58]. Moreover, the amount of KW had a significant impact on the duration of biogas production which plummeted from 20 days for $50 \% \mathrm{KW}$ in D2 to 12 days for $75 \% \mathrm{KW}$ in D4 (Fig. 3). However, the peak production was observed as $150 \mathrm{~mL}$ in $\mathrm{D} 2$ at the second day of digestion. In spite of that, D3 with $67.7 \% \mathrm{KW}$ and $33.3 \% \mathrm{PM}$ proves to be the optimum ratio in terms of CBG production, sustained biogas production, and moderate inhibitory effect from PM. This percentage of PM is believed to have provided balanced nutrient for the anaerobic microorganisms and enhanced buffering capacity to the digester through ammonia production. In the presence of ammonia, it has been reported that the gas production occurred due to the activity of hydrogenotrophic methanogens since acetotrophic methanogens are more sensitive to the ammonia level [59].

\subsection{Effect of temperature on biogas production}

Temperature plays a significant role in the anaerobic digestion process by controlling the rate of microbial metabolism in anaerobic environments [60, 61]. Findings of several studies indicate that there is a positive relationship between the temperature and the production of biogas [62]. There are mainly three different temperature ranges in which AD can be operated: psychrophilic $\left(<30^{\circ} \mathrm{C}\right)$, mesophilic $\left(30-40{ }^{\circ} \mathrm{C}\right)$, and thermophilic $\left(50-60{ }^{\circ} \mathrm{C}\right)$ [63]. Though thermophilic $\mathrm{AD}$ has been reported to produce higher biogas and give better quality digestate [64], it has also been observed that this type of AD suffer from instability. The fluctuation arises due to inhibition from high amount of ammonia release during organic nitrogen removal [65] and higher accumulation of VFAs due to slow metabolic and growth rate of acetoclastic methanogens [66, 67]. Moreover, thermophilic digestion is not an economically viable option due to its requiring large energy input for heating the system and associated operational difficulties [68]. Several authors also suggested mesophilic temperature range for optimum biogas production [61, 69]. Considering economic feasibility and process stability, mesophilic temperature of $37^{\circ} \mathrm{C}$ was applied to the digesters to investigate the effect of temperature on biogas production.

Daily gas production (Fig. 5) and the associated $\mathrm{pH}$ change (Fig. 6) during the mesophilic digestion showed a similar trend to that of at room temperature (described in Sect. 3.2). The gas production (Fig. 5) increased initially and then followed a period of declination which was continued by a steady growth and then a final drop until it stops. The $\mathrm{pH}$ of all digesters (Fig. 6) observed a gradual drop initially up to 6 to 10 days and then hovered over that constant value until the cessation of gas production. The highest $\mathrm{pH}$ drop was observed in D1 with $100 \% \mathrm{KW}$ and the lowest $\mathrm{pH}$ drop was observed in D3 with $66.7 \% \mathrm{KW}$. D3 achieved the highest peak production of $390 \mathrm{~mL}$ on the 10th day of digestion and is also the digester yielding highest CBG which is 920 $\pm 11 \mathrm{~mL}$. However, all the digester setups gave higher CBG than those at the room temperature, as delineated in Table 3 and Fig. 7.

\subsection{1 •}

The percentage increase in CBG production was $66.26 \%$, $69.61 \%, 132 \%$, and $25.56 \%$ for D1, D2, D3, and D4, respectively. Liu et al. [70] also observed a greater efficiency in biogas production from the co-digestion of animal waste and 
Fig. 5 Daily biogas production at mesophilic temperature $\left(37^{\circ} \mathrm{C}\right)$

Fig. 6 Daily $\mathrm{pH}$ change during biogas production mesophilic temperature $\left(37^{\circ} \mathrm{C}\right)$
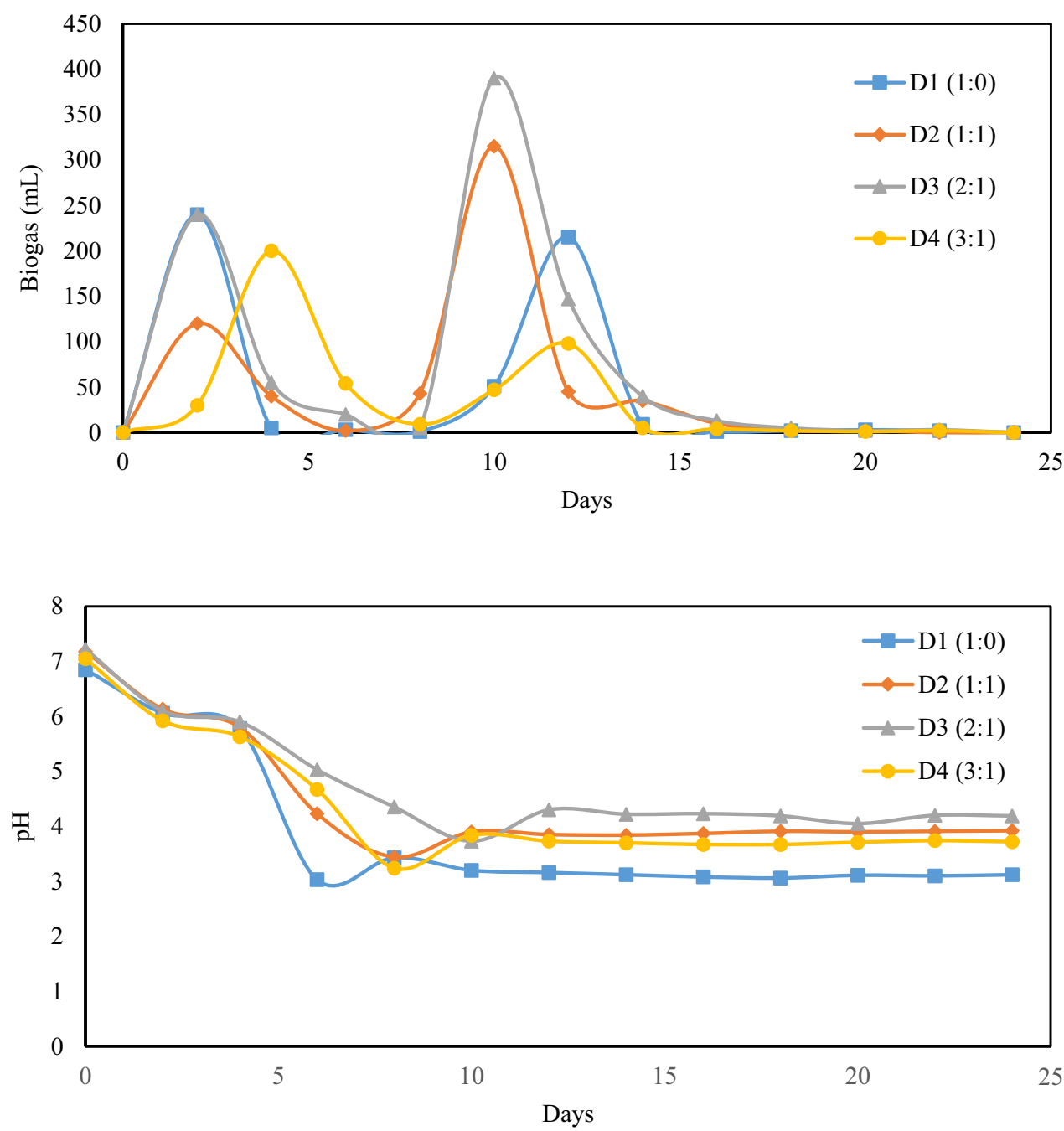

Fig. 7 Comparison of CBG production at different biomass ratios at room temperature $28^{\circ} \mathrm{C}$ (dotted line) and mesophilic temperature $37^{\circ} \mathrm{C}$ (solid line)

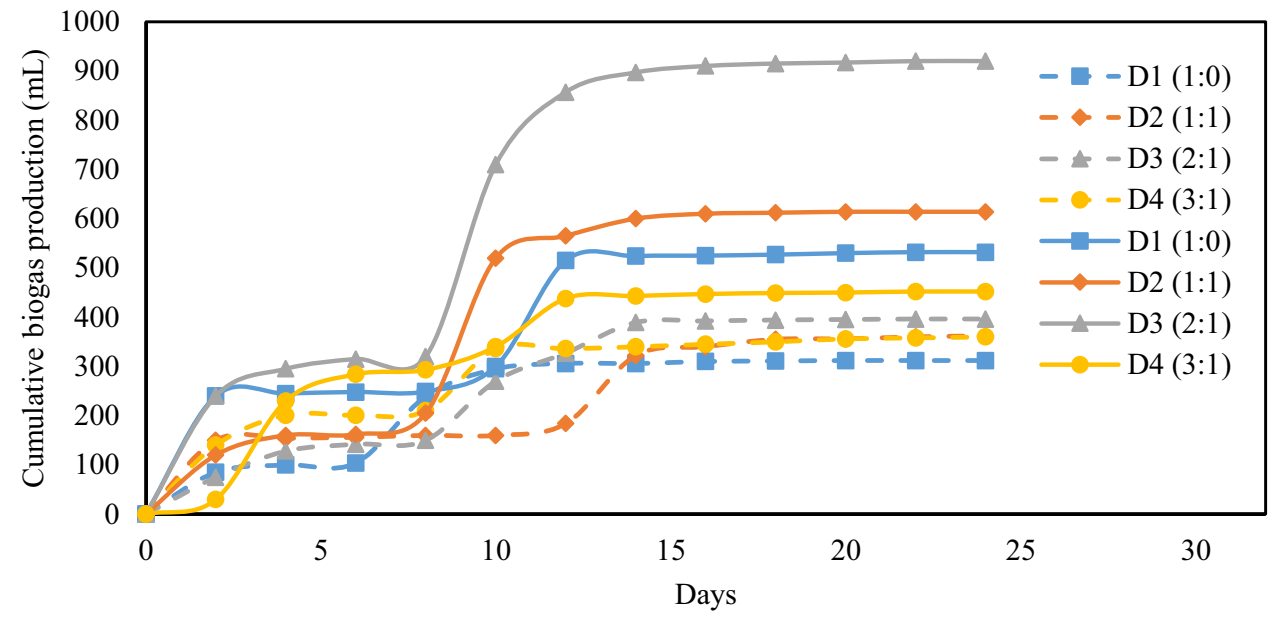

agricultural waste in the mesophilic temperature range. The reason can be attributed to the enhancement of the anaerobic degradation of the complex organic matters facilitated by the increased hydrolysis rate $[71,72]$; a peak production on the 10th day can be considered as a testimony to this phenomenon. The substrate degradation rate was higher in mesophilic condition than the room temperature as compared in Fig. 8. It has been demonstrated that the activity and growth 
Fig. 8 Degradation rate at room temperature $\left(28^{\circ} \mathrm{C}\right)$ vs. mesophilic temperature $\left(37^{\circ} \mathrm{C}\right)$

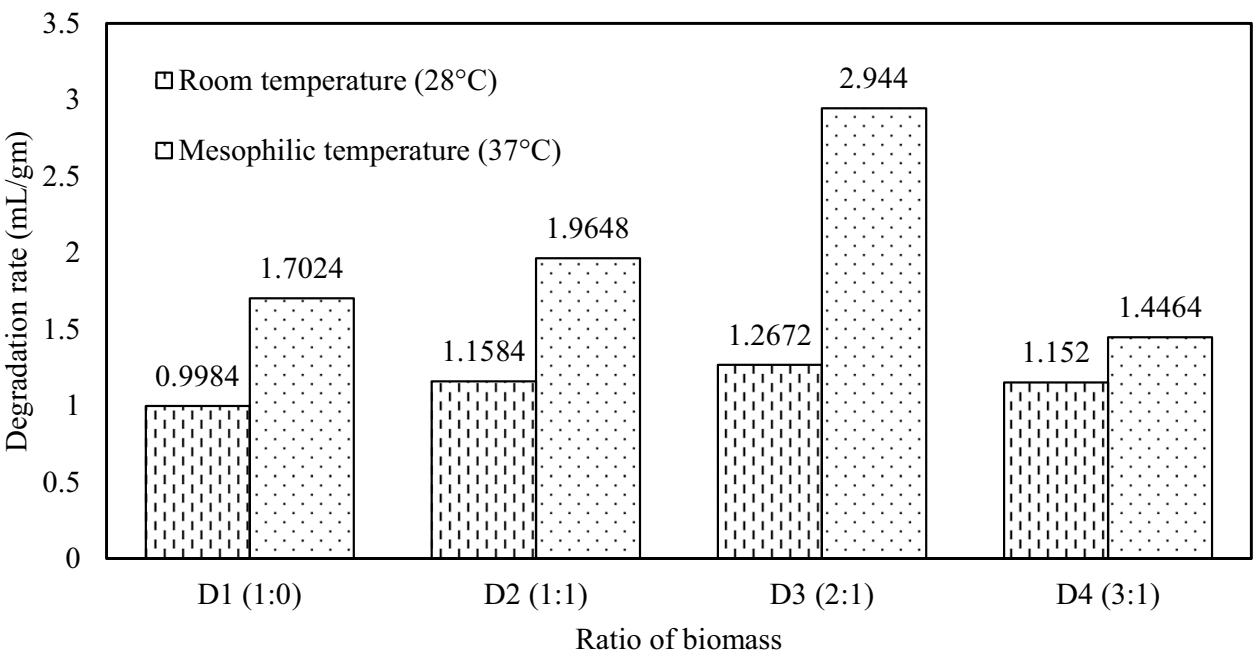

Table 4 Comparison of methane percentage in biogas at room temperature $\left(28^{\circ} \mathrm{C}\right)$ and mesophilic temperature $\left(37^{\circ} \mathrm{C}\right)$

\begin{tabular}{lll}
\hline Digester setup & $\begin{array}{l}\text { Methane percentage at } \\
28{ }^{\circ} \mathrm{C}\end{array}$ & $\begin{array}{l}\text { Methane } \\
\text { percentage at } \\
37^{\circ} \mathrm{C}\end{array}$ \\
\hline D1 & $19 \%$ & $23 \%$ \\
D2 & $33 \%$ & $48 \%$ \\
D3 & $36 \%$ & $48 \%$ \\
D4 & $31 \%$ & $43 \%$ \\
\hline
\end{tabular}

rate of microbes increase by up to $50 \%$ for a temperature rise of $10{ }^{\circ} \mathrm{C}$ within the mesophilic range [73]. However, digester setup D2 containing high amount of protein $(50 \%$ $\mathrm{PM}$ ) experienced lower biogas production than $\mathrm{D} 3$ because of the increased inhibition from free ammonia due to shift in $\mathrm{NH}_{3} / \mathrm{NH}_{4}{ }^{+}$equilibrium at high temperature [62]. On the other hand, lower biogas production in D4 was observed due to acidic environment from the increased hydrolysis of organics [74] in 70\% KW; the lowest $\mathrm{pH}$ of $\mathrm{D} 4$ among the co-digesters corroborates this assertion.

\subsection{Methane percentage observation}

Methane is the prime energy source in biogas, and the higher is the methane content, the better is the biogas quality. Table 4 compares the methane percentage in the produced biogas at room temperature $\left(28^{\circ} \mathrm{C}\right)$ and mesophilic temperature $\left(37^{\circ} \mathrm{C}\right)$. It can be seen that, irrespective of the temperature, biogas from D1 had the lowest methane percentage. This can be attributed to the acidification of the digester from rapid hydrolysis of readily available organic matters $(100 \% \mathrm{KW})$ that led to lower growth and activity of methanogens. A similar phenomena was observed by $\mathrm{Li}$ et al. [36] while digesting $\mathrm{KW}$ alone and reported that higher food to microorganism ratio caused lower methanogenic activity. However, replacement of some KW with PM increased the methane percentage significantly. It is noted that PM is highly rich in undigested protein content [75]. Kafle and Kim [76] reported that the presence of protein in one substrate could facilitate the methane production. This is mainly due to the synergistic effect of co-digestion stemming from proper $\mathrm{C} / \mathrm{N}$ ratio and increased buffering capacity [51]. At room temperature, D2 obtained 33\% methane-containing biogas, while for D3 and D4, it was $36 \%$ and $31 \%$, respectively. Methane content was highest in D3 because of the enhanced buffering capacity provided by the ammonia degraded from protein in PM. Moreover, the 33.3\% PM in $\mathrm{D} 3$ provided a balanced nutrient for anaerobic bacteria. However, D2 experienced less methane content owing to inhibition from excess ammonia produced from 50\% PM. Excess ammonia also inhibits methane production by facilitating accumulation VFAs since acetotrophic methanogens are more sensitive to ammonia [59]. In contrast, in D4, the lower percentage of methane might be attributed to poor neutralization of the VFAs by insufficient amount of ammonia produced from $25 \% \mathrm{PM}$.

However, at $37^{\circ} \mathrm{C}$, the methane percentages increased significantly and were above $40 \%$ in all the digester setups except D1. Typically, methane percentage in biogas that is exploitable for energy usage ranges from 40 to $75 \%$ [58]. Heavy acidification and lower $\mathrm{pH}$ in D1 from increased degradation of $\mathrm{KW}$ alone played an inhibitory effect on methanogens. Surge in methane percentage can be attributed to the increased acetate and propionate degradation efficiency with the increasing temperature [77]. Moreover, higher hydrolysis rate, microbial growth, and activity at mesophilic temperature range were also responsible for augmented methane percentage. The result of this study is consistent with the findings of Wang et al. [78] who observed an increase in methane percentage at mesophilic temperature when codigested dairy manure, PM, and rice straw. 


\section{Conclusion}

$\mathrm{AD}$ is a promising approach to curtail the ever-increasing load of KW in an environment friendly way through the production of clean energy such as biogas. However, the digestion of KW alone experiences VFA accumulation due to the easy biodegradability of the organics leading to $\mathrm{pH}$ drop - an environment hostile for methanogenic bacteria that cause lower CBG production with lower methane content. This study found that the co-digestion of KW with PM can improve the biogas production by enhancing the buffering capacity of the digester stemming from the ammonia released by the decomposition of organic nitrogen in PM. Compared to the mono-digestion of $\mathrm{KW}$, a $16 \%$ increase in biogas production was observed when $50 \% \mathrm{KW}$ was replaced by PM during the co-digestion process. However, the co-digestion of KW and PM showed considerable dependency on substrate ratio and process temperature. At room temperature $\left(28^{\circ} \mathrm{C}\right)$, the highest $\mathrm{CBG}$ production of $396 \pm 8 \mathrm{~mL}$ was observed in digester setup D3 with a KW and $\mathrm{PM}$ ratio of 2:1, which can be attributed to the balanced nutrient and $\mathrm{pH}$ stability in the digester. At mesophilic condition $\left(37^{\circ} \mathrm{C}\right), \mathrm{CBG}$ production of all the digesters increased due to the increase in hydrolysis of organics and activity of microbes. Among the digester setups, D3 yielded the highest biogas of $920 \pm 11 \mathrm{~mL}$ which was $132 \%$ higher than that of the room temperature. The methane percentage in the produced biogas also followed the similar trend of CBG production in terms of dependency on substrate ratio and process temperature. Digester setup D3 was found to produce biogas with highest methane percentage of $36 \%$ and $48 \%$ at $28{ }^{\circ} \mathrm{C}$ and $37^{\circ} \mathrm{C}$, respectively. Therefore, the present study suggests that anaerobic co-digestion of $\mathrm{KW}$ and PM in proper ratio could be a sustainable way to mitigate the environmental problem and energy crisis simultaneously.

\subsection{Limitation of the work}

Due to the current COVID-19 pandemic situation that forced the laboratory to be remained off until further notice, we could not conduct and include experimental data regarding the changes in VFAs and COD values during the digestion period.

\section{Declarations}

Conflict of interest The authors declare no competing interests.

\section{References}

1. Kumar M, Srivastava N, Upadhyay S, and Mishra P (2021) Thermal degradation of dry kitchen waste: kinetics and pyrolysis products. Biomass Convers Biorefin:1-18. https://doi.org/10. 1007/s13399-021-01309-z

2. Nanda S, Berruti F (2020) Municipal solid waste management and landfilling technologies: a review. Environ Chem Lett 13:1433-1456. https://doi.org/10.1007/s10311-020-01100-y

3. Abdel-Shafy HI, Mansour MS (2018) Solid waste issue: sources, composition, disposal, recycling, and valorization. Egypt J Pet 27(4):1275-1290. https://doi.org/10.1016/j.ejpe.2018.07.003

4. Wang F, Cheng Z, Reisner A, Liu Y (2018) Compliance with household solid waste management in rural villages in developing countries. J Cleaner Prod 202:293-298. https://doi.org/10. 1016/j.jclepro.2018.08.135

5. National Restaurant Association (2020) Restaurant industry facts at a glance. https://restaurant.org/research/restaurant-stati stics/restaurant-industry-facts-at-a-glance. Accessed $27 \mathrm{Feb}$ 2021

6. Nelson C and Lamb J (2002) Final report: Haubenschild farms anaerobic digester updated! https://www.cleanenergyresourcet eams.org/sites/default/files/publication_files/Haubyrptupdated. pdf. Accessed 27 Feb 2021

7. Alastair JW, Phil JH, Peter JH, David LJ (2008) Optimisation of the anaerobic digestion of agricultural resources. Bioresour Technol 99(17):7928-7940. https://doi.org/10.1016/j.biortech. 2008.02.044

8. Jarwar AI, Laghari AQ, Maitlo G, Qureshi K et al (2021) Biological assisted treatment of buffalo dung and poultry manure for biogas generation using laboratory-scale bioreactor. Biomass Convers Biorefin:1-8. https://doi.org/10.1007/ s13399-020-01248-1

9. Waste Concern (2014) Bangladesh waste database 2014. http:// wasteconcern.org/wpcontent/uploads/2016/05/Waste-Data-Base_ 2014_Draft-Final.pdf. Accessed 25 Feb 2021

10. Enayetullah I, Sinha AMM, and Khan SSA (2005) Urban solid waste management scenario of Bangladesh: problems and prospects. Waste Concern. https://www.semanticscholar.org/paper/ URBAN-SOLID-WASTE MANAGEMENTSCENARIO-OF BANGLADESH/5d48094ce4cf1743e0b3eb7dcdeeeeafd4b12998. Accessed 25 Feb 2021

11. Hoornweg D and Bhada-Tata P (2012) What a waste: a global review of solid waste management. World Bank Group. https:// openknowledge.worldbank.org/handle/10986/17388. Accessed 25 Feb 2021

12. Islam K (2016) Municipal solid waste to energy generation in Bangladesh: possible scenarios to generate renewable electricity in Dhaka and Chittagong city. J Renew Energy 2016.https://doi. org/10.1155/2016/1712370

13. Alam O, Qiao X (2020) An in-depth review on municipal solid waste management, treatment and disposal in Bangladesh. Sustain Cities Soc 52:101775. https://doi.org/10.1016/j.scs.2019.101775

14. Islam KN (2017) Greenhouse gas footprint and the carbon flow associated with different solid waste management strategy for urban metabolism in Bangladesh. Sci Total Environ 580:755-769. https://doi.org/10.1016/j.scitotenv.2016.12.022

15. Khan I (2020) Waste to biogas through anaerobic digestion: hydrogen production potential in the developing world-a case of Bangladesh. Int J Hydrog Energy 45(32):15951-15962. https:// doi.org/10.1016/j.ijhydene.2020.04.038

16. Amanullah MM, Somasundaram E, Vaiyapuri K, Sathyamoorthi K (2007) Poultry manure to crops-a review. Agric Rev 28(3):216-222

17. Myhre G, Shindell D, Pongratz J (2014) Anthropogenic and natural radiative forcing, climate change. In Climate change 2013 - the physical science basis: Working Group I Contribution to the Fifth Assessment Report of the Intergovernmental Panel on Climate Change:659-740. https://doi.org/10.1017/CBO9781107415324. 018 
18. Hasan MK, Shahriar A, Jim KU (2019) Water pollution in Bangladesh and its impact on public health. Heliyon 5(8):e02145. https:// doi.org/10.1016/j.heliyon.2019.e02145

19. Dana T (2011) Hospital waste management: Bangladesh. OIDA Int J Sustain Dev 2(9):29-40

20. Gagliardi R (1982) Cogeneration in a commercial environment: paper incineration with heat recovery, electricity, space heating and cooling. In: Advances in energy productivity. Fairmont Press, Atlanta, pp 125-128

21. Ucuncu A, Veisilind A (1993) Energy recovery from mixed paper waste. Waste Manag Res 11(6):507-513. https://doi.org/10.1006/ wmre.1993.1053

22. Domalski E, Churney K, Ledford A Jr, Bruce S (1986) Monitoring the fate of chlorine from MSW sampling through combustion Part I: analysis of the waste stream for chlorine. Chemosphere 15(9-12):1339-1354. https://doi.org/10.1016/0045-6535(86) 90409-1

23. Bünsow W, Dobberstein J (1987) Refuse-derived fuel: composition and emissions from combustion. Res Conserv 14:249-256. https://doi.org/10.1016/0166-3097(87)90026-5

24. Zhang Z, Zeng Q, Hao R, He H et al (2019) Combustion behavior, emission characteristics of $\mathrm{SO} 2, \mathrm{SO} 3$ and $\mathrm{NO}$, and in situ control of $\mathrm{SO} 2$ and $\mathrm{NO}$ during the co-combustion of anthracite and dried sawdust sludge. Sci Total Environ 646:716-726. https://doi.org/ 10.1016/j.scitotenv.2018.07.286

25. Hsieh Y-K, Chen W-S, Zhu J, Huang Q (2018) Characterization of polychlorinated dibenzo-p-dioxins and dibenzofurans of the flue gases, fly ash and bottom ash in a municipal solid waste incinerator. Aerosol Air Qual Res 18(2):421-432. https://doi.org/10.4209/ aaqr.2017.12.0564

26. De Andres JM, Narros A, Rodríguez ME (2011) Air-steam gasification of sewage sludge in a bubbling bed reactor: effect of alumina as a primary catalyst. Fuel Process Technol 92(3):433-440. https://doi.org/10.1016/j.fuproc.2010.10.006

27 Choi Y-K, Cho M-H, Kim J-S (2016) Air gasification of dried sewage sludge in a two-stage gasifier. Part 4: application of additives including Ni-impregnated activated carbon for the production of a tar-free and $\mathrm{H} 2$-rich producer gas with a low $\mathrm{NH} 3$ content. Int J Hydrog Energy 41(3):1460-1467. https://doi.org/10. 1016/j.ijhydene.2015.11.125

28. Jayaraman K, Gökalp I (2015) Pyrolysis, combustion and gasification characteristics of miscanthus and sewage sludge. Energy Convers Manage 89:83-91. https://doi.org/10.1016/j.enconman. 2014.09.058

29. Striūgas N, Valinčius V, Pedišius N, Poškas R et al (2017) Investigation of sewage sludge treatment using air plasma assisted gasification. Waste Manage 64:149-160. https://doi.org/10.1016/j. wasman.2017.03.024

30. Gil-Lalaguna N, Sánchez J, Murillo M, Rodríguez E et al (2014) Air-steam gasification of sewage sludge in a fluidized bed. Influence of some operating conditions. Chem Eng J 248:373-382. https://doi.org/10.1016/j.cej.2014.03.055

31. Unpaprom Y, Pimpimol T, Whangchai K, Ramaraj R (2020) Sustainability assessment of water hyacinth with swine dung for biogas production, methane enhancement, and biofertilizer. Biomass Convers Biorefin:1-12. https://doi.org/10.1007/ s13399-020-00850-7

32. Odekanle E, Dahunsi S, Zahedi S (2020) Anaerobic treatment of abattoir waste: biogas production and correlation parameter in a batch reactor system. J Water Process Eng 37:101337. https://doi. org/10.1016/j.jwpe.2020.101337

33. Zala M, Solanki R, Bhale PV, Vaishak S (2019) Experimental investigation on anaerobic co-digestion of food waste and water hyacinth in batch type reactor under mesophilic condition. Biomass Convers Biorefin:1-8. https://doi.org/10.1007/ s13399-019-00522-1
34. Jiang Y, Heaven S, Banks C (2012) Strategies for stable anaerobic digestion of vegetable waste. Renewable Energy 44:206214. https://doi.org/10.1016/j.renene.2012.01.012

35. Dahunsi S, Osueke C, Olayanju T, Lawal A (2019) Co-digestion of Theobroma cacao (Cocoa) pod husk and poultry manure for energy generation: effects of pretreatment methods. Bioresour Technol 283:229-241. https://doi.org/10.1016/j.biortech.2019. 03.093

36. Li R, Chen S, Li X, Saifullah Lar J et al (2009) Anaerobic codigestion of kitchen waste with cattle manure for biogas production. Energy Fuels 23(4):2225-2228. https://doi.org/10.1021/ ef 8008772

37. Abouelenien F, Kitamura Y, Nishio N, Nakashimada Y (2009) Dry anaerobic ammonia-methane production from chicken manure. Appl Microbiol Biotechnol 82(4):757-764. https:// doi.org/10.1007/s00253-009-1881-3

38. Procházka J, Dolejš P, Máca J, Dohányos M (2012) Stability and inhibition of anaerobic processes caused by insufficiency or excess of ammonia nitrogen. Appl Microbiol Biotechnol 93(1):439-447. https://doi.org/10.1007/s00253-011-3625-4

39. Callaghan FJ, Wase D, Thayanithy K, Forster C (1999) Codigestion of waste organic solids: batch studies. Bioresour Technol 67(2):117-122. https://doi.org/10.1016/S0960-8524(98) 00108-4

40 Mata-Alvarez J, Macé S, Llabres P (2000) Anaerobic digestion of organic solid wastes. An overview of research achievements and perspectives. Bioresour Technol 74(1):3-16. https://doi.org/10. 1016/S0960-8524(00)00023-7

41. Ye J, Li D, Sun Y, Wang G et al (2013) Improved biogas production from rice straw by co-digestion with kitchen waste and pig manure. Waste Manag 33(12):2653-2658. https://doi.org/10. 1016/j.wasman.2013.05.014

42. Wang X, Yang G, Feng Y, Ren G et al (2012) Optimizing feeding composition and carbon-nitrogen ratios for improved methane yield during anaerobic co-digestion of dairy, chicken manure and wheat straw. Bioresour Technol 120:78-83. https://doi.org/10. 1016/j.biortech.2012.06.058

43. Hartmann H, Angelidaki I, Ahring BK (2000) Increase of anaerobic degradation of particulate organic matter in full-scale biogas plants by mechanical maceration. Water Sci Technol 41(3):145153. https://doi.org/10.2166/wst.2000.0066

44. American Public Health Association, American Water Works Association, Water Pollution Control Federation, \& Water Environment Federation (1912) Standard methods for the examination of water and wastewater (Vol. 2)

45. Tasnim F, Iqbal SA, Chowdhury AR (2017) Biogas production from anaerobic co-digestion of cow manure with kitchen waste and Water Hyacinth. Renew Energy 109:434-439. https://doi.org/ 10.1016/j.renene.2017.03.044

46. Iqbal SA, Rahaman S, Rahman M, Yousuf A (2014) Anaerobic digestion of kitchen waste to produce biogas. Procedia Eng 90:657-662. https://doi.org/10.1016/j.proeng.2014.11.787

47. Chuenchart W, Logan M, Leelayouthayotin C, Visvanathan C (2020) Enhancement of food waste thermophilic anaerobic digestion through synergistic effect with chicken manure. Biomass Bioenergy 136:105541. https://doi.org/10.1016/j.biombioe.2020. 105541

48. Wang K, Yin J, Shen D, Li N (2014) Anaerobic digestion of food waste for volatile fatty acids (VFAs) production with different types of inoculum: effect of pH. Bioresour Technol 161:395-401. https://doi.org/10.1016/j.biortech.2014.03.088

49. Kafle GK, Kim SH (2013) Anaerobic treatment of apple waste with swine manure for biogas production: batch and continuous operation. Appl Energy 103:61-72. https://doi.org/10.1016/j. apenergy.2012.10.018 
50. Bres P, Beily ME, Young BJ, Gasulla J et al (2018) Performance of semi-continuous anaerobic co-digestion of poultry manure with fruit and vegetable waste and analysis of digestate quality: a bench scale study. Waste Manag 82:276-284. https://doi.org/10.1016/j. wasman.2018.10.041

51. Li Y, Zhang R, Liu X, Chen C et al (2013) Evaluating methane production from anaerobic mono-and co-digestion of kitchen waste, corn stover, and chicken manure. Energy Fuels 27(4):20852091. https://doi.org/10.1021/ef400117f

52. Bujoczek G, Oleszkiewicz J, Sparling R, Cenkowski S (2000) High solid anaerobic digestion of chicken manure. J Agric Eng Res 76(1):51-60. https://doi.org/10.1006/jaer.2000.0529

53. Borowski S, Weatherley L (2013) Co-digestion of solid poultry manure with municipal sewage sludge. Bioresour Technol 142:345-352. https://doi.org/10.1016/j.biortech.2013.05.047

54. Ayotamuno M, Kogbara R, Ogaji S, Probert S (2006) Petroleum contaminated ground-water: remediation using activated carbon. Appl Energy 83(11):1258-1264. https://doi.org/10.1016/j.apene rgy.2006.01.004

55. Xia T, Huang H, Wu G, Sun E et al (2018) The characteristic changes of rice straw fibers in anaerobic digestion and its effect on rice straw-reinforced composites. Ind Crops Prod 121:73-79. https://doi.org/10.1016/j.indcrop.2018.04.004

56. Lin J, Zuo J, Gan L, Li P et al (2011) Effects of mixture ratio on anaerobic co-digestion with fruit and vegetable waste and food waste of China. J Environ Sci 23(8):1403-1408. https://doi.org/ 10.1016/S1001-0742(10)60572-4

57. Park S, Li Y (2012) Evaluation of methane production and macronutrient degradation in the anaerobic co-digestion of algae biomass residue and lipid waste. Bioresour Technol 111:42-48. https://doi.org/10.1016/j.biortech.2012.01.160

58. Bharathiraja B, Sudharsana T, Jayamuthunagai J, Praveenkumar R et al (2018) Biogas production-a review on composition, fuel properties, feed stock and principles of anaerobic digestion. Renew Sustain Energy Rev 90(C):570-582. https://doi.org/10. 1016/j.rser.2018.03.093

59. Xia Y, Massé DI, McAllister TA, Kong Y et al (2012) Identity and diversity of archaeal communities during anaerobic co-digestion of chicken feathers and other animal wastes. Bioresour Technol 110:111-119. https://doi.org/10.1016/j.biortech.2012.01.107

60. Appels L, Van Assche A, Willems K, Degrève J et al (2011) Peracetic acid oxidation as an alternative pre-treatment for the anaerobic digestion of waste activated sludge. Bioresour Technol 102(5):4124-4130. https://doi.org/10.1016/j.biortech.2010.12.070

61. Dahunsi S, Oranusi S, Owolabi JB, Efeovbokhan VE (2016) Mesophilic anaerobic co-digestion of poultry dropping and Carica papaya peels: modelling and process parameter optimization study. Bioresour Technol 216:587-600. https://doi.org/10.1016/j. biortech.2016.05.118

62. Tassew FA, Bergland WH, Dinamarca C, Bakke R (2020) Influences of temperature and substrate particle content on granular sludge bed anaerobic digestion. Appl Sci 10(1):136. https://doi. org/10.3390/app10010136

63. Sreekrishnan T, Kohli S, Rana V (2004) Enhancement of biogas production from solid substrates using different techniques-a review. Bioresour Technol 95(1):1-10. https://doi.org/10.1016/j. biortech.2004.02.010

64. Ge H, Jensen PD, Batstone DJ (2011) Relative kinetics of anaerobic digestion under thermophilic and mesophilic conditions. Water Sci Technol 64(4):848-853. https://doi.org/10.2166/wst. 2011.571

65. Sanchez E, Borja R, Weiland P, Travieso L et al (2000) Effect of temperature and $\mathrm{pH}$ on the kinetics of methane production, organic nitrogen and phosphorus removal in the batch anaerobic digestion process of cattle manure. Bioprocess Eng 22(3):247252. https://doi.org/10.1007/s004490050727

66. Lianhua L, Dong L, Yongming S, Longlong M et al (2010) Effect of temperature and solid concentration on anaerobic digestion of rice straw in South China. Int J Hydrogen Energy 35(13):72617266. https://doi.org/10.1016/j.ijhydene.2010.03.074

67. Speece R, Boonyakitsombut S, Kim M, Azbar N et al (2006) Overview of anaerobic treatment: thermophilic and propionate implications. Water Environ Res 78(5):460-473

68. Chae K, Jang A, Yim S, Kim IS (2008) The effects of digestion temperature and temperature shock on the biogas yields from the mesophilic anaerobic digestion of swine manure. Bioresour Technol 99(1):1-6. https://doi.org/10.1016/j.biortech.2006.11.063

69. Franqueto R, da Silva JD, Konig M (2019) Effect of temperature variation on codigestion of animal waste and agricultural residue for biogas production. Bioenergy Res:1-13. https://doi.org/10. 1007/s12155-019-10049-y

70. Liu C, Wachemo AC, Tong H, Shi S et al (2018) Biogas production and microbial community properties during anaerobic digestion of corn stover at different temperatures. Bioresour Technol 261:93-103. https://doi.org/10.1016/j.biortech.2017.12.076

71. Bouallagui H, Haouari O, Touhami Y, Cheikh RB et al (2004) Effect of temperature on the performance of an anaerobic tubular reactor treating fruit and vegetable waste. Process Biochem 39(12):2143-2148. https://doi.org/10.1016/j.procbio.2003.11.022

72. Veeken A, Hamelers B (1999) Effect of temperature on hydrolysis rates of selected biowaste components. Bioresour Technol 69(3):249-254. https://doi.org/10.1016/S0960-8524(98)00188-6

73. Krátký L, Jirout $\mathrm{T}$ (2013) The effect of mechanical disintegration on the biodegradability of wheat straw. Inz Ap Chem 52(3):202 203. http://www.inzynieria-aparaturachemiczna.pl/pdf/2013/ 2013-3/InzApChem_2013_3_202-203.pdf. Accessed 5 Jan 2021

74. Rattanapan C, Sinchai L, Tachapattaworakul Suksaroj T, Kantachote $\mathrm{D}$ et al (2019) Biogas production by co-digestion of canteen food waste and domestic wastewater under organic loading rate and temperature optimization. Environments 6(2):16. https://doi. org/10.3390/environments6020016

75. Nahm K (2003) Evaluation of the nitrogen content in poultry manure. World's Poult Sci J 59(1):77-88. https://doi.org/10.1079/ WPS20030004

76. Kafle GK, Kim SH (2013) Effects of chemical compositions and ensiling on the biogas productivity and degradation rates of agricultural and food processing by-products. Bioresour Technol 142:553-561. https://doi.org/10.1016/j.biortech.2013.05.018

77. Bohn I, Siversson B, Batstone D, Björnsson L, et al. (2001) Anaerobic digestion of agriculture residues under psychrophlilic conditions. In: Proceedings of the 9th World Congress Anaerobic Digestion. IWA Antwerpen. Belgium, pp 2-6

78. Wang X, Lu X, Li F, Yang G (2014) Effects of temperature and carbon-nitrogen $(\mathrm{C} / \mathrm{N})$ ratio on the performance of anaerobic codigestion of dairy manure, chicken manure and rice straw: focusing on ammonia inhibition. PLoS ONE 9(5):e97265. https://doi. org/10.1371/journal.pone.0097265

Publisher's note Springer Nature remains neutral with regard to jurisdictional claims in published maps and institutional affiliations. 